\title{
For soldier and state: dual loyalty and World War One
}

\author{
Leo van Bergen \\ Medical historian, KITLV-Leiden (Royal Netherlands Institute of South East Asian and Caribbean \\ Studies)
}

Published in: Medicine, Conflict and Survival, 28, 4 (Oct.-Dec. 2012) 291-308

\section{Summary}

Military medicine has always been characterised by some form of dual loyalty. The physician had to look at the interests of the individual soldier-patient as well as the state and the military in general. How each individual doctor related to this has mostly been subscribed to war circumstances on the one and personnel character and/or religious and ideological beliefs on the other. Taking World War One as an example Van Bergen shows that also the nature of the illness or wound had some say in this. The disfigured were looked upon mainly out of patient's interests; the invalidated out of as well patient's as state interest, and the neurotic mainly out of the interests of the state.

\section{Keywords}

World War One, military medicine, dual loyalty, disability, disfigurement, psychiatry, military history, medical history

\section{Introduction}

The relationship between war and medicine can be looked upon in several ways. One could talk about the nature of the wounds or illnesses, about the actual treatment the sick and wounded are given, or about the way medical care is organized in different nations or wars. One could focus on the doctors and nurses, as has often been done, or focus on the patient. (Van Bergen 2009) One could argue the often subscribed thesis 'war is good for medicine', (Lanz 1925) by some changed into 'medicine is good for war' (Cooter 1994; Van Bergen 2007) or even 'medicine should stay away from war'. (Joules 1938; Van Bergen 2011) This article, however, explores the reasons behind medical care, looking at World War One. What comes 
to the fore when reading articles and books regularly published on war and medicine is that not only the treatment of several wounds and illnesses in the medical sense of the word differed, but also in the moral. The 'pity', so to say, was unequally divided. Wounded, for instance, could count on more understanding than the diseased, (Hirschfeld 1978; Winter 1979) also after the war, when the permanently diseased had a far tougher job of being recognized as a war-invalid and therefore receive a pension.

The title 'For Soldier and State' refers to what in human rights circles is called 'dual loyalty'. Dual loyalty, for instance also influencing company or insurance physicians, certainly in wartime is never completely absent. In theory it ranges from how best to take care of the patient (mostly without completely forgetting state's interest), to focusing on how to safeguard the interests of state and army (mostly without completely forgetting the patient's interest). The boundaries of this range however have regularly been transgressed. If this happened in favour of the soldier-patient it could lead to conflict with a military superior. (Babington 1997) If it happened in favour of the state or army it led to medical care choices described as excellent and justified at that particular time and place, but in hindsight often considered highly unethical. An example of this last stand was presented by a British physician who admitted, when giving evidence after the war before the Shell Shock Committee, that to achieve his goal, which was 'to maintain the discipline and morale of his unit', 'the health of individuals may have to be sacrificed temporarily, even permanently'. (Simpson 1996)

The place the individual doctor takes in this range is determined by differing things like individual character or religious belief, and state ideology or military urge for soldiers. Contributing are the status of the medical specialism (or the way in which circumstances can be used to enhance this status) and the medical urge for experimenting, consent or not, either out of personal interest or national or medical importance. Dalton Trumbo's (1999) Johnny got his Gun, published shortly before WWII, is the ultimate example of medical experiment on invalided WWI-soldiers making it at the same time the ultimate anti-war novel; a novel German doctor and historian Theodor Lessing (1986) would have wholeheartedly embraced if he had not been killed by the SA in 1933. War, he wrote, was one big experiment in natural science for the benefit of politicians, army chiefs and doctors, who reasoned that war would be good for medicine and for the mental and physical condition of the soldier. 
About what do the doctors speak to the nursing staff? About daring operations, unprecedented tests, new medicines, bold physiological trials. And what was a person and what was a soul? Material.

It was an experiment involving a wealth of encounters with bacteria and unhygienic conditions rare in peacetime, immediately reducing the supposed goodness of war for medicine. (Lerner 2003; Eckart, Gradmann 1996; Ruprecht, Jenssen 1991; Lemercier 1918; Cooter 1994; Kaufmann 1999; Van Bergen 2007)

In spite of some fierce differences of opinion, most physicians during WWI agreed that, at least in theory, the circumstances of war had severely altered the doctor-patient relationship and that completely justified this change was not in favour of the patient. Refusing necessary treatment, according to the doctors, was comparable to refusing a military order (unless the treatment was deemed life-threatening). This theory was hardly affected by the apparent difficulty of acting in accordance with it. For instance, as far as is known really harsh measures were seldom taken to enforce obedience. According to Susanne Michl (2007) most doctors tried to get their way by pointing to a presumed higher morality and to the sense of guilt many sick and wounded felt towards their colleagues who had remained in the trenches. But however they interpreted this in practice, most physicians during 1914-1918 were convinced that they had not only to keep the patients' interests in mind, but also those of their nation in arms.

To say that dual loyalty to Mars and Hippocrates has been characteristic of healthcare in wartime does not of course mean that each individual doctor related to it in the same manner and to the same degree, as said depending on personal character, ideological or religious beliefs and circumstances determined by time and place. What I would like to discuss in this review, taking the facially disfigured, the disabled and the neurotics as an example, is that as well as the above mentioned criteria, the nature of the wound or disease itself partly determined the doctors' position within the dual loyalty range.

\section{The importance of medicine for warfare}

Why was this theoretically everlasting dilemma not of any practical importance until the middle of the nineteenth century? Simply because before that time medical care hardly had really life-saving effects. Previously practitioners, with the best of intentions, often achieved 
little or no result and none within the time-span of a war. Seldom did a wounded soldier return to the battlefield, or survive the war without the removal of one or more of his limbs. Cynics would say that the sick and wounded were not healed because of, but in spite of the physician. Because of its growing life-saving power, however, medicine became of military importance. It therefore is not to be wondered at that this was precisely when the Red Cross movement came into being. Hence the success of this organisation - which was not the first of its kind, but the first to survive - is better explained by looking at military rather than humanitarian reasons (van Bergen 1994, Hutchinson 1996).

Before 1850, before the era of the Crimean, American Civil or Franco-Prussian wars, chances of soldiers surviving an illness or wound were negligible and money spent on medical care was from a military point of view good for morale at best, but in terms of the strength of the army or navy, in fact wasted. Of course there had been doctors we now call eminent before the revolution in medicine, such as the famous Dominique Jean Larrey or PierreFrançois Percy during the Napoleonic wars, but the chances of being treated by them, let alone saved, were about as slim as the chances of falling victim to a terrorist attack nowadays statistically speaking negligible. From the mid nineteenth century the chances of surviving warrelated diseases gradually began to rise and WWI was the first in which more soldiers died of battle wounds resulting from enemy or friendly fire than of disease, making medical care into an important source of 'fresh' warriors.

Of course this operational usefulness of healthcare for the military had not gone unnoticed and soon after the beginning of the war the number of personnel in the medical services proliferated. For instance, the British Royal Army Medical Service counted 20,000 doctors and nurses in 1914; in 1918 they had 160,000. The American army had 500 doctors when the United States declared war on Germany in 1917; in 1918 the number had risen to 31,000 (Garrison 1970; Verdoorn 1995; Winter 1979). Numbers alone do not tell the entire tale. In his Healing the Nation Jeffrey S. Reznick (2005) shows that hospitals and rest-huts were not only important for the rest and cure of the wounded or war-weary soldier, but for the war-machine as well. As a result the soldier's image of them was at best ambivalent, seen as they were as an escape from front and no man's land and as an extension of them. How the sick and wounded were treated fitted in, or was fitted in, a society focused on winning a war. 
It is a conclusion Mark Harrison $(2004 ; 2010)$ probably will subscribe. He has made perfectly clear in his The Medical War on WWI and Medicine \& Victory on WWII, that medical care has become an important, even indispensable part of waging (a victorious) war.

\section{Characteristics of the First World War}

In WWI more soldiers fought than ever before; soldiers had to fight for a longer stretch of time than ever before; they fought on battlefields vaster than ever before; and they had to move further away from the battlefield before being safe from the millions of grenades hurled through the air almost constantly and from the resulting shrapnel and debris flying across the so-called 'field of honour', mutilating everybody getting in its way. Because of this it was a war in which the percentage of soldiers who died was twice as high as it would be in 1939-1945. (Winter 1979; Binneveld 1995). Furthermore, new kinds of weaponry were used and existing weapons deployed to military benefit, but humanitarian detriment. The machine-gun is perhaps the best example. There were only a handful of Maxim and Lewis-guns in August 1914 , but their number, not unlike the number of doctors, soon began to rise fast, becoming the hallmark of infantry. Along with the war-defining artillery and barbed wire, it gave defence the advantage at a time when attacking to the utmost, the attaque a outrance, dominated military theory. A second conundrum was that although defence was more successful, the war could only be won and ended by offence (Ellis 1976).

Another characteristic of WWI was the in general right-wing, war-endorsing conviction of physicians. Rehabilitation was of importance as US-orthopaedic J.S. Goldthwait said, because it made the disabled, mostly former working class soldiers less 'centres of revolution'. (Linker 2011) German soldier Ernst Toller (1984), as Britain's Siegfried Sassoon a decorated officer turning into a war-critique, was imprisoned where he fell ill. Before refusing the feverish patient a second blanket the first doctor treating him said 'all pacifists should be executed'. A second one took a poetry book from his bedside table. 'Anyone who reads such bilge shouldn't be surprised to fetch up in prison.'

\section{Death and injury in 1914-1918}

This combination of on the one hand aggressive theory and necessity, and millions of soldiers with, after a while, a vast war-strengthening healthcare provision, led by (wo)men subscribing the war-aims, and on the other hand an enormous amount of effective defensive weaponry, 
resulted in about 20,000 wounded per day for over four years and three months, not counting the sick, of which of course a significant number died before any medical care could be, or was given. Incidentally, only a small percentage of those deaths were caused by poison gas nowadays known as one of the three weapons of mass destruction, but because of this small percentage after the war by chemists and military men not seldom pictured as a humane weapon. (Van Bergen 2008)

The damage done by shell and bullet was hardly imaginable, as for instance C.R.M.F. Cruttwell admits. 'The extent to which a human body can be mangled by the splinters of a bomb or shell, without being deprived of consciousness, must be seen to be believed.' (Wilson 1986) But however terrible, most men survived. In his book Vie des Martyrs French doctor and author Georges Duhamel (1922) described soldiers with dozens of wounds and/or body parts torn off. Yet they lived. However, as Frank Richards wrote, that most survived did not reduce the terror these wounds evoked.

I wasn't worrying so much if a shell pitched clean amongst us: we would never know anything about it. It was the large flying pieces of shell bursting a few yards off that I didn't like: they could take arms and legs off or, worse still, rip our bellies open and leave us still living. We would know something about them all right. (Terraine 1978)

Naturally the almost uninterrupted flood of wounded was hardly controllable in spite of the enormous number of doctors and nurses, but when there were heavy battles such as Verdun, Somme or Ypres III, chaos ruled. For instance, the complete, meticulously planned medical route from stretcher bearer to base hospital, set up by the British before the battle of the Somme, immediately became obsolete. No planning could solve the problems caused by 20,000 dead and particularly 40,000 wounded on one day (Middlebrook 2001; Fussell 1992; Gilbert 1994; Harrison 2010).

All those wounded needed care. On the one hand because otherwise even more of them would die, arousing the opposition of the 'Hippocrates' within medical men, and on the other hand, because if possible these wounded had to be made fit for battle again, in deference to the inner 'Mars'. And if this showed to be impossible, it had to be prevented that all of them would receive pensions, for this would lead to the state's bankruptcy. Therefore, specialist hospitals were created all over the warring countries in which it was tried to 
restore each man as much as possible to his previous vigour so that he could function in society again. What effect did this have on the therapy these doctors gave to the wounded? As said I will limit myself to three categories: the facially disfigured, the disabled, and the neurotics.

\section{The disfigured}

Although fifty percent of facial wounds were fatal wounds, thousands were left permanently disfigured by flamethrower, shrapnel or shell fragments, often so severe that a man could indeed be said to have lost his face. (Gabriel, Metz 1992) Men like John Bagot Glubb, who was chatting with a comrade when he suddenly thought he could hear an incoming shell. He was right.

For an instant I appeared to rise slowly into the air and then slowly to fall again. ... I could feel something lying loosely in my left cheek, as though I had a chicken bone in my mouth. It was in reality half my jaw, which had been broken off, teeth and all, and was floating about in my mouth. (Bamji 1996)

The sight facially disfigured often turned one's stomach. Enid Bagnold (1917) wrote of a man without a profile. 'Like an ape, he has only his bumpy forehead and his protruding lips - the nose, the left eye, gone.' There also was a man without nostrils, struggling to breathe through two rubber tubes. 'It gave him a more horrible look to his face than I have ever seen.' Bagnold believed the medical orderly was convinced he would not survive and she asked herself whether the soldier in question might actually prefer that to the prospect of living, a question Ludwig Renn (1929) also must have asked himself when witnessing a man whose nose and mouth were nothing but a bloody lump. How could he still be alive? How does he eat? Would he not die of starvation?

Therapy was aimed primarily at making the face as whole, as good, as possible. It is important to note that these soldiers were of no importance for battle, nor would they ever be again, if only because they would not leave a hospital specialised in facial reconstruction until long after the war was over. Twenty different operations on one single patient were anything but an exception. Pointing to important historical figures such as the Dutch Johannes Esser, working in Berlin, Vienna and Budapest, or British Harold Gillies, in his famous Sidcup hospital, 
it has often been said that because of WWI facial surgery made a giant step forward. Much can be and has been said about this, but what is important is to be aware that even so facial surgery was still in its infancy at the end of the war. Inevitably a point was reached when the surgeons could do no more and although most patients certainly looked far better than they had, their faces often still were hideous. Probably more than ever in history, 'better' showed itself to be a relative term. Having been almost or completely faceless, they now looked like Frankenstein monsters or, as one of the nurses said, gargoyles (Fussell 1992; Bamji 1998).

So the question became, how do these people in spite of their gruesome fate ever regain their places in society? This was considered of utmost importance, on the one hand for the patients themselves who would have a better self-image and more self-confidence if they had a job or could even start a family, but on the other hand also for the state. For if it would not be possible giving the facially disfigured a proper place in society, they could turn out to be extremely costly. One of the solutions to this problem was the manufacturing of masks to be put on when stepping outside the safe boundaries of the hospital walls, (Macdonald 1984) turning Frankenstein's monsters into Phantoms of the Opera.

These masks certainly were successful, but evidently they only kept the gruesome truth out of sight and not take it away. They only postponed showing the truth to the outside world, a truth which, certainly when engaging in a relationship, had to come out into the open sooner or later. As a result, in spite of the masks, a sizeable proportion of the disfigured never set foot outside hospital doors, at least not for a considerable time. Only inside hospital walls where other disfigured patients, doctors and nurses were used to them, could they be themselves. Incidentally this acceptance certainly took some time, especially for the nurses. They were the ones most directly involved with the patients, fear of whom was not uncommon at first - solely because of the way they looked. (Bamji 1996, Heijster 1998)

On the inside the disfigured made themselves useful as housekeepers, gardeners, cooks or even nurses. In this way at least one of the objectives was reached. Although one could hardly say that they had become part of society - that society often did not even know of their existence - because of their activities they were not a burden to society either. Nevertheless, the pity surely was more on the patients' side as on the state.

\section{The disabled}


As the disfigured, the war-invalids too would not make any further contribution to the wareffort, at least not as soldiers. Thousands lost one or more limbs on the field of battle and the sight of men on crutches, in wheelchairs or with bound-up sleeves became a normal one in countries at war - so normal that British historian Joanna Bourke (1996) thinks that the Great War completely changed the way we look upon the male body or manliness altogether. And if conceptions of manliness change, those of femininity change as well, as Ana Carden-Coyne (2009) explored thoroughly in her Reconstructing the Body.

This change was not only the result of the physical consequences of invalidity. Up until then emotions and feelings were 'feminine'. Men were beings of reason and emotional restraint. But the loss of hands also meant the loss of touch, the loss of actual feeling, so important in emotional feeling. When discussuing a soldier who had lost both of his hands, French soldier-author Gabriel Chevallier (2009) wrote that this was even more pitiable because the ability to feel was perhaps our most valuable sense. And in his poem 'Disabled', dated 1917, Wilfred Owen (1997) wrote about an equal patient: 'Now he will never feel again how slim/ Girls' waists are, or how warm their subtle hands.' In his next line he showed that being touched would also never be the same again: 'All of them touch him like some queer disease', later adding: 'Tonight he noticed how the women's eyes/ Passed from him to the strong men that were whole.' The loss of actual feeling, as important a sense as seeing or hearing, is very much in need of further research.

So, the invalid's fate partly resembled and partly differed from that of the disfigured, but, as said, from a military point of view the common factor was the impossibility of serving in the forces. However, he literally was not worthless. If an acceptable prosthesis was delivered the disabled could still make a valuable contribution to the war effort and after the war to society in general. The pity, so to say, still was there, but began to show its boundaries and conditions. As British orthopaedic Robert Jones stated: the disabled had to be 'independent producers and wage-earners', instead of 'helpless dependents' and War Cabinet secretary Thomas Jones supported the work of orthopaedics like Jones, because they prevented Britain from getting flooded 'with thousands of untrained idle pensioners'. (Linker 2011)

It was an idea also non-medics more or less embraced. In his introduction to the report of a Franco-British conference about care for disabled ex-servicemen, author John Galsworthy, very much dedicated to the well-being of disabled soldiers, (Reznick 2009) wrote: 
The flesh torn away, the lost sight, the broken ear-drum, the destroyed nerve, it is true we cannot give back; but we shall so re-create and fortify the rest of him that he shall leave hospital ready for a new career. (Reznick 2000)

In other words: by repairing his body as far as possible and then restoring a man's selfconfidence and personal pride, the disabled soldier could be turned back into a healthy individual, a physically strong male breadwinner and a productive citizen.

In countries like Germany and France orthopaedic hospital schools and vocational workshops became an integrated part of defence strategy. American orthopaedics began to define themselves as the 'social guardians' of the nation. As moderately wounded had to be made fit for combat, disabled had to be made fit for factory work. Beth Linker (2011) wrote in her War's Waste on American war-invalids: 'Ultimately this demand for functioning male bodies made rehabilitation seem like a necessity to the success of any modern state at war.' In America rehabilitation even became mandatory. 'If a disabled soldier refused rehabilitation, he faced the possibility of being dishonourably discharged and thus forced to relinquish all other benefits that come with military service.' As a consequence, although his disability - unless of course self-inflicted or the result of an accident - proved he had bravely done his bit, unlike earlier wars he no longer automatically was portrayed a hero. For that he also had to do everything he could to be whole again, a man again, an economically independent man taking care for wife and kids.

Those who succeeded, a minority, were held as example for all those who did not, or simply could not like the man Leonhard Frank (1918) witnessed. He had not lost a limb, his spine had been hit. For the rest of his life he would have to go jack-knifed, since his torso and legs were permanently fixed at an angle of ninety degrees.

Furthermore, no matter how many limbs were manufactured in the combatant countries, there were never enough, if only because half were rejected by the body. (Winter 1979) This was kept from the men, as was the fact that the artificial limbs the body did accept were far from perfect, also because the conveyor belt-technique was introduced, producing cheaper prostheses to fit all (or at least the white male) almost, but not fitting anyone perfect. (Linker 2011) Dearden, who always, even when he knew better, told soldiers that they would survive, tried to convince the gravely wounded that the damage to their 
bodies would not hamper them in later life. 'I don't think he heard many of the lies I told him about men who could do everything with an artificial leg that they could ever do before, but there is really nothing else you can say.' (Dearden 1928) Stefan Zweig (1974) even wrote of doctors praising their prostheses so extravagantly that one almost felt like opting for voluntary amputation. (also: Riemann 1930) It nevertheless shows the vast number of invalids gave the opportunity not only to restore the human being, restoring humanity, but also creating a new human being, innovating humanity. The similarity is that restoration and innovation both kept an eye on state interest, including a direct financial one by giving the opportunity to get an income, but also with an eye to its future economic power. (Macdonald 1984; Perry 2003; Sassoon 1972; Weldon 1984)

Often the prosthesis was adjusted to the former, often industrial, functions the invalid had fulfilled, although if the state's interests demanded it he could also find himself back in agriculture. This meant that a civil servant who lost his legs was entitled to a wooden replacement leg, but in the case of a lost arm he could receive a highly technical prosthesis enabling him to type again. By the end of the war, certainly in Germany, orthopaedists had developed dozens of different types of arms and legs, all tailored to the economic function the disabled man was expected to fulfil. Their aim was to reduce the financial burden to the state by helping the disabled wherever possible to resume his former - or a new occupation. This also gave them the state's support. Therefore it benefitted patient, doctor and nation, making the handicapped soldier a metaphor for the wounded state. The state had to recover, and therefore the disabled man had to recover. The healing of the disabled healed the nation. Many doctors claimed that with the help of artificial limbs recovery was always possible, unless a disabled soldier, suffering from 'pension neurosis', did not really want to get well. (Perry 2003; Macdonald 1984; Whalen 1984)

All this means Linkers (2011) conclusion on the US can be internationalized. 'What animated the practice of orthopedic surgery and rehabilitation was the creation of future citizens: taking a maimed body and repairing it in the hopes that someday it would be put to use in the industrial workplace', or, as she said in her article 'Feet for Fighting: locating disability and social medicine in First World War America', orthopaedic surgeons contended that physical disability was as much of a threat to national health as germs and believed that debilitating conditions [...] should be prevented and cured for the general betterment of American society.' (Linker 2007) And Heather Perry (2011) concluded that WWI showed the 
importance of orthopaedics for the war-effort, giving it status (and shifting its focus from deformed children to victims of severe trauma). Not for nothing in her PhD on WWI Germany, Recycling the Disabled, she talks about the 'economy of the body', with which she meant the 'classification, ranking and distribution of the state's human resources in the most efficient manner possible in order to support the wartime nation'. (Perry 2005)

\section{The war-neurotics}

One of the equivalents between facial surgery, orthopaedics and psychiatry/neurology was that the war provided opportunities to proof the worth of the specialism for country, King or Kaiser. In his book Hysterical Men Paul Lerner (2003) describes the work of German neurologist Kurt Singer, who wrote in early 1915 that a strong nervous system was the key to military success. Strong nerves were indispensable to military discipline, since they enabled a man to obey. This meant that psychiatry had a major role to play in warfare, alongside other important areas of medical activity such as surgery, internal medicine and hygiene. (also: Riemann 1930)

The defining difference between neurasthenics and hysterics on the one hand and the facially disfigured and war-disabled on the other was that in the case of the latter one could actually see that they had been wounded by war. In those days certainly many non-medical military men, and also many physicians, were convinced that an invisible ailment was not an ailment at all. A second difference was that the risk of causing or aggravating harm to themselves was considerably greater in the group of psychologically damaged. Naturally many soldiers wounded themselves or tried to fake mental or physical illness (Bourke 1996; Sassoon 1972; Schrep 2004), but the number deliberately removing an arm or leg, or cutting their own face to bits, will have been relatively small. This meant too that unlike psychological illness or wounding, fear of an epidemic effect was absent in the case of disfigurement and disability. Fear of an epidemic of war-neurotics was all too real. (Babington 1997; Winter 1979; Bourke 1996; Myers 1940; Binneveld 1995; Bourke 1999; Shephard 2000).

These differences are crucial if the nature of rehabilitation and the arguments behind it are to be explained. Within the category of mental problems one has also to consider whether the diagnosis (which could easily be wrong) was hysteria or neurasthenia or shellshock-sick or shellshock-wounded or whatever. The difference between the first two was that neurasthenia could also have external causes such as the stress of war, whereas hysteria was explained 
entirely as a character weakness of the patient himself or perhaps an inherited family disease. Neurasthenia was therefore less stigmatizing. This explains why even when symptoms were similar hysteria was more likely to be the diagnosis for a soldier of lower rank, whereas an officer, coming from the same social class as the physicians, would be declared neurasthenic, (Myers 1940, Young 1995, Mosse 1998, Kaufmann 1999, Bourke 2000, Hofstra and Porter 2001, Busfield 2003), although recent research has shown that class differences in diagnosis were, at least in Germany, probably not as great as often has been thought. (Peckl 2011)

The difference between 'sick' and 'wounded' was of importance for other reasons. The war changed definitions. 'Sick' meant one was either sick or wounded, not as a result of the fighting, and 'wounded' meant one was either sick or wounded, for sure as a result of the fighting. One could get 'sick' anytime and anywhere and so there need not be a relationship with the war. Therefore the diagnosis 'sick' gave no right to a war-pension, in contrast to the diagnosis 'wounded'. Doctors were expected to declare as many patients as possible sick. Naturally this was especially the fate of the psychologically damaged because of the aforementioned unfamiliarity and invisibility, even denial of the phenomenon, because of the suspicion and possibility of simulation, and because of the attempt to prevent an outbreak of a psychiatric epidemic. After strenuous but fruitless attempts to get rid of the term 'shellshock' and replace it with the much more neutral, not war-related, terminology 'Not Yet Diagnosed (Nervous)', in September 1918 it was forbidden for British doctors to declare patients shellshock-wounded. Every shell-shocked soldier was shellshock-sick, although as with hysteria the cause of this mental illness was supposed to be inside the patient himself, and was therefore more stigmatizing than the term shellshock-wounded. It must however be said that this measure was partly the result of the habit of some doctors, knowing that they had far too little knowledge of psychological problems to make a trustworthy diagnosis, always declared their patients wounded. (Babington 1997, Myers 1040, Whitehead 1997)

In Germany in 1916 the theory of traumatic neurosis, nowadays at the heart of posttraumatic stress disorder (PTSD), was declared wrong and out of date. The few who kept clinging on to it marginalised themselves within the occupational group. The shared assumption became that war in itself could not be a reason for psychological suffering, on the contrary. So in fact every neurotic was sick instead of wounded. And if there was nevertheless a connection between war and madness, at best it was that the war had functioned as the 
spark setting the already present weakness of the nerves in motion (Kaufmann 1999; Micale, Lerner 2001; Lerner 2003; Eckart, Gradmann 1996; Jones, Wesseley 2005).

As a consequence, in general the shellshock-cases and the Kriegszitterer were not to be envied, and this goes for the ones suffering from trouble nerveux as well. Psychiatric hospital should, at least for the soldiers amongst the patients, not be a safe haven, not a place of rest from the front or their superiors, but a place resembling a military barracks as much as possible.

There were many different treatments for serious cases, but they all came down to a very forceful, authoritarian, swift sort of therapy - by the British called 'quick cure' by the Germans Überrumpelungsmethode -, guaranteeing success and success meaning 'disappearance of symptoms'. Looking at the cause of the symptoms, for instance limbs refusing to work without a detectable, physical reason, was of no importance. The patient - a soldier, officers were all but spared these harsh treatments - was not allowed to leave the room, referred to by some as the torture chamber, before the doctor had reached his goal. Sessions therefore had to be short, and therefore had to involve fierce intimidation often accompanied by hypnosis or the administration of electricity, followed by the command: 'Thou shalt heal' (Binneveld 1995; Van der Ploeg, Weerts 1995; Young 1995; Bourke 1999; Shephard 2000; Kaufmann 1999; Gijswijt-Hofstra, Porter 2001; Micale, Lerner 2001; Lerner 2003; Eckart, Gradmann 1996; Jones, Wessely 2005; Binneveld 2003; Binneveld 2007; Lerner 1999; Roudebush 1999; Leed 1979; Hirschfeld 1978; Shephard 1999).

Medical historians Peter Riedesser and Axel Verderber (1985) wrote with some cynicism in their book Aufrüstung der Seelen that there were some brave men who endured all this and had themselves carried to the graveyard in small coffins. 'But there were also faint-hearted people who, once they got to the enemas, declared that they already felt much better and wanted nothing other than to leave for the front with the next battalion.' They concluded that the psychiatrists were 'not the medical advocates' of war-neurotics but 'conscious helpers of a military leadership that demanded the smooth functioning of the soldier and where necessary his rapid return to combat readiness'. (Riedesser, Verderber 1985)

Psychoanalyst Fritz Wittel, in his novel Zacharias Pamperl, published in 1923, supported this verdict wholeheartedly, although one should keep in mind that he also 
wanted to prove the goodness of Freud's followers and the wickedness of biological psychiatrists.

These gentlemen used machines generating electrical currents, such as are used in America against armed robbers who kill, and they tickled the defenders of the fatherland until no option was left to them but suicide or a return to the gunfire. They injected them with emetics, so that they spewed up their very souls and preferred death for the fatherland to going on living like that. Maria Theresa had abolished torture; the nerve doctors reintroduced it during this war. (Hirschfeld 1978)

One great difference in ways of looking at the mentally disturbed between the British and the French on the one hand, and the Germans on the other, has to be mentioned. In general the Germans spoke of the neurasthenic in economic terms. These soldiers were comparable to workers on strike, which for many, including many as said often politically conservative physicians, was about the same as lazy workers. As the striking worker in the interest of the state had to get back as soon as possible into the factory, the striking soldier had to get back to delivering his part of the war effort as soon as possible. However, partly because of this comparison, German psychiatrists and neurologists were often satisfied if the patient could be transferred to a war factory, which also kept him from returning to hospital within days. In the factory the soldier who had been declared healed could heal still further and prove that he had shaken off his condition of idleness.

In contrast the British and French spoke of psychologically damaged in terms of masculinity and femininity. If he was unable to handle the stress of war the soldier was proved to have lost his masculinity and become feminised. What test was more suitable to prove that his masculinity had been restored than renewed service at the frontline? (Micale, Lerner 2001; Lerner 1999; Lerner 2003; Eckart, Gradmann 1996; Jones, Wessely 2005; Shephard 1999).

But within blocks there were differences too. In an excellent article Hans Georg-Hofer (2011) makes the influence of context to medical practice perfectly clear, when arguing that electric treatment in the Austrian army was used longer and harsher than elsewhere. Their multi-ethnic and multi-lingual army was desperately in need of a treatment in which there was hardly any need of talking. 
A parallel between the two sides was that, as with the weapons-factory in Germany, frontline service for the British and French mentally ill was both part as goal of the treatment. The longer one was able to stay in the trenches, the more one's regained masculinity was proved and reinforced. A second resemblance was that much more than in the case of the facially disfigured, with reference to whom state interest were secondary, and more than in that of the maimed, for whom renewed fighting was out of the question, both the Central Powers and the Entente wished to keep the cost of therapy for neurotics as low as possible and the war effort on track. With them, the pity was at its lowest and so it would stay after the war.

Like the command to declare nobody shellshock-wounded any more, medical policy was strengthened by political measures. France, for instance, in principle never gave pensions to war-neurotics. Nevertheless, it has to be said that these measures were not only the result of misplaced frugality or an aversion to those who made a fuss. It also could be the result of bitter financial necessity, certainly in the Weimar Republic which in addition to fighting economic depression had to fulfil its financial obligations as agreed in the Treaty of Versailles. As a result Weimar had a very restricted pension policy and the war-neurotics were the main victims. From 1926 it was impossible for them to receive a pension. According to some doctors this had a distinct healing effect: it prevented them from getting a pension neurosis as well. Moreover many regarded them not as victims of war but as Jews, communists and anarchists, being supposedly guilty of the German defeat by 'stabbing the army in the back'. Therefore, a pension would be an award for betrayal. (Whalen 1984; Lerner 1999; Shephard 2000; Cohen 2000; Cohen 2001).

\section{Dual loyalty and the role of illness}

All this means that on the aforesaid spectrum between looking after the interests of the patient and those of state and army, therapy for the facially disfigured must be placed at the 'patient' end, for invalids somewhere in the middle, and what the physicians had in store for 'lunatics' at the state or army end. And according to many the neurotics' 'therapy' not infrequently broke through the boundaries of humanity. Not for nothing accusations were made against some doctors, already during the war but mainly after 11 November 1918, having consequences for patient autonomy. But before this autonomy was completely 
recognised another war had to be fought, including even harsher violations of medical ethics. (Binneveld 1995; Shephard 2000; Kaufmann 1999; Lerner 1999; Roudebush 2009; Klee 1997)

\section{Conclusions}

The way illnesses and wounds were treated by doctors in the First World War (or war in general, for that matter) is partly determined by dual loyalty to the individual patient on the one side and state and army on the other. The way individual doctors tried to cope with this is often ascribed to ideology, religion and/or character. However, the illness or wound itself also determined if and in how far the interests of the patient were considered to be of more or less value than those of state and army. This means that the harshness of which especially psychiatrists and neurologists are often accused, was not, or at least not only, a result of personnel, but also of professional characteristics.

\section{References}

Babington, A., 1997. Shell-Shock. A history of the changing attitudes to war neurosis, London: [Leo Cooper], pp. 87-88, 96-97, 104-105, 120.

Bamji, A., 1996. Facial surgery: the patient's experience. In: Hugh Cecil, Peter H. Liddle (eds.), Facing Armageddon. The First World War Experience, London: [Pen \&Sword], pp. 490-501. Bamji, A., 1998. The Queen's Hospital, Sidcup. Physical and psychological rehabilitation after facial injury 1917-1925 [unpublished manuscript] pp. 4-6 Bagnold, E., 1978, A Diary Without Dates, London: [William Heinemann] 1917, p. 8. Barton, G. ed., without year. The Voices of the Great War, without place: [Longman], pp. 4546.

Bergen, L. van, 1994. De Zwaargewonden Eerst. Het Nederlandsche Roode Kruis en het vraagstuk van oorlog en vrede 1867-1945 (The Severely Wounded First? The Dutch Red Cross and the question of war and peace), Rotterdam: [Erasmus Publishing], pp. 37-91.

Bergen, L. van, 2009. Before my Helpless Sight. Suffering, dying and military medicine on the Western front 1914-1918, Farnham: [Ashgate].

Bergen, L. van, 2008. The poison gas debate in the inter-war years. In: Medicine Conflict and Survival, 24 (3), pp. 174-187. 
Bergen, L. van, 2011, 'Would it not be better to just stop?' Dutch medical aid in World War I and the medical anti-war movement in the Interwar years, in: First World War Studies, 2, nr. 2, pp. $165-194$

Binneveld, H., 1995. Om de geest van Jan Soldaat. Beknopte geschiedenis van de militaire psychiatrie (For the Mind of Tommy Atkins. A short history of military psychiatry), Rotterdam: [Erasmus Publishing], pp. 47, 52, 100, 139-140, 142-143, 145-148.

Binneveld, H., 1995. Herstel op bevel. Beknopte geschiedenis van de militaire psychiatrie (Curing by order. A concise history of military psychiatry), in: H.M. van der Ploeg, J.M.P. Weerts (eds.), Veteranen in Nederland (Veterans in the Netherlands), Lisse, [Swets \& Zeitlinger] pp. 63-76.

Binneveld, H., 2003. Shell Shock Versus Trouble Nerveux. In: Hans Andriessen et al. (eds.), De Grote Oorlog. Kroniek 1914-1918, (The Great War) part 3, Soesterberg, [Aspekt], pp. 54-71. Binneveld, H., 2007. Beter worden op bevel. De psychisch gewonde soldaat en het ontstaan van de militaire psychiatrie (Healing on Command. The psychologically wounded soldier and the creation of military psychiatry). Kleio, Dec. 2007, pp. 30-33.

Bourke, J., 1996. Dismembering the Male. Men's bodies, Britain and the Great War, London: [University of Chicago Press], esp. pp. 86, 109-110, 112, 116.

Bourke, J., 1999. An Intimate History of Killing. Face-to-face killing in twentieth-century warfare, London: [Granta], pp. 252-253.

Bourke, J., 2000. Effeminacy, ethnicity and the end of trauma: the sufferings of "shell-shocked" men in Great Britain and Ireland 1914-39. In: Journal of Contemporary History, 35, 1, pp. 57-69. Busfield, J., 2003. Class and Gender in Twentieth-Century British psychiatry: shell-shock and psychopathic disorder. In: Jonathan Andrews, Ann Digby (eds.), Sex and Seclusion, Class and Custody, Amsterdam/New York: [Rodopi] pp. 295-322.

Chevallier, G., 2009. Heldenangst (orig.: La Peur), Amsterdam [Cossee], p. 85.

Cohen, D., 2000. Will to work: disabled veterans in Britain and Germany after the First World War. In: David A. Gerber, ed., Disabled Veterans in History, Michigan: [University of Michigan Press] pp. 295-321.

Cohen, D., 2001. The War Come Home. Disabled veterans in Britain and Germany, 19141939, Los Angeles/London: [University of California Press], pp. 3, 7-9, 12.

Cooter, R., 1994, War and Modern Medicine. In: W.F. Bynum, R. Porter (eds.), Companion Encyclopedia of the History of Medicine, London/New York: [Routledge], 1536-1572. 
Dearden, H., 1928. Medicine and Duty. A war diary, London: [Heinemann], pp. 31-32, 152.

Duhamel, G.. 1922, Vie des Martyrs, Paris : [Mercure de France] (orig. 1917), p. 137

Eckart, W.U., Gradmann, C. (eds.),1996. Die Medizin und der Erste Weltkrieg, Pfaffenweiler, [Centaurus], pp. 13, 93-96, 212.

Ellis, J., 1976. The Social History of the Machine Gun, London: [Pimlico] 1976, pp. 113-116, 128129, 135, 142.

Frank, L., 1918, Der Mensch ist Gut, Zürich: [Max Rascher Verlag] (6-15 thousand), p. 167. Fussell, F. (ed.), 1992. The Bloody Game. An anthology of modern war, London: [Abacus] pp. $33,60,169$.

Gabriel, R.A., Metz, K.S., 1992. A History of Military Medicine, London: [Greenwood Press], part II: From the Renaissance through modern times, p. 242.

Garrison, F.H., 1970. Notes on the History of Military Medicine, New York: [Georg Olms], pp. 196-197.

Gilbert, M., 1994. First World War, London: [Weidenfeld and Nicholson] pp. 261-262.

Gijswijt-Hofstra, M., Porter, R., 2001. Cultures of Neurasthenia. From Beard to the First World War, Amsterdam/New York: [Rodopi] pp. 10, 16, 377.

Harrison,. M., 1996. The Medicalization of War - The Militarization of Medicine. Review article, in: Social History of Medicine, 9, 2, pp. 267-276.

Harrison, M., 2004, Medicine and Victory. British military medicine in the Second World War, Oxford: [Oxford University Press].

Harrison, M., The Medical War. British military medicine in the First World War, Oxford: [Oxford University Press].

Heijster, R., 1998. leper 14/18 (Ypres), Tielt [Lannoo], p. 158.

Hirschfeld, HM., 1978. Sittengeschichte des 1. Weltkrieges (Sexual History of the First World War), Hanau [Karl Schustek], pp. 185, 359-360.

Hofer, H.G., 2011. Beyond Freud and Wagner-Jauregg: War, psychiatry and the Habsburg Army, in: Hans-Georg Hofer, Cay-Rüdiger Prüll, Wolfgang U. Eckart (eds.), War, Trauma and Medicine in Germany and Central-Europe (1914-1939), Freiburg: [Centaurus], pp. 49-71. Hutchinson, JF., 1996. Champions of Charity. War and the rise of the Red Cross, Oxford/Boulder: [Westview Press] pp. 57-104.

Jones, E., Wessely, S., 2005. From Shell Shock to PTSD: military psychiatry from 1900 to the War, New York: [Maudsley Monographs / Psychology Press] pp. 14-15, 38-39. 
Joules, H., 1938. The Doctor's View of war, London: [George Allen \& Unwin], pp. 7-10. Kaufmann, D., 1999. Science as a cultural practice: psychiatry in the First World War and Weimar Germany, in: Journal of Contemporary History, 34, 1, pp. 125-144.

Klee, E., 1997. Auschwitz, die NS-Medizin und ihre Opfer (Auschwitz. National Socialist medicine and its victims), Frankfurt a/M.: [S. Fischer] p. 116.

Lanz. O., 1925. De Oorlogswinst der Heelkunde (The benefit of war for surgery), Utrecht: [Utrecht University] Leed, L., 1979. No Man's Land. Combat \& identity in World War I, Cambridge: [Cambridge University Press] pp. 174-175.

Lemercier, E.E., 1918. Lettres d'un soldat, Paris: [Chapelot], p. 146.

Lerner, P., 1999. Psychiatry and Casualties of War in Germany, 1914-1918, in: Journal of Contemporary History, 34, 1 (Jan. 1999), pp. 13-28.

Lerner, P., 2003. Hysterical Men: war, psychiatry, and the politics of trauma in Germany, 18901930, London: [Cornell University Press] pp. 1, 41-52, 63-64, 67-71, 74-85, 102, 126, 138, 160, 219-220.

Lessing, T., 1986. Das Lazarett, in: Theodor Lessing, Ich warf eine Flaschenpost im Eismeer der Geschichte. Essays und Feuilletons 1923-1933, Darmstadt: [Luchterhand], pp. 354-386. Linker, B., 2007. Feet for Fighting: locating disability and social medicine in First World War America, in: Social History of Medicine, vol. 20, no. 1, 91-109, p. 91

Linker, B., 2011. War's Waste. Rehabilitation in World War I America, Chicago: [University of Chicago Press], pp. 38, 51, 53-54, 56-57, 60, 114-115

Macdonald, L., 1984. The Roses of No Man's Land, London: [Penguin Books] pp. 147, 149, 151, 154.

Micale, M., Lerner, P. (eds.), 2001. Traumatic Pasts. History, psychiatry and trauma in the modern age, 1870-1930, Cambridge: [Cambridge University Press] pp. 142, 157, 160, 162-163, 170-171, 270.

Michl, S., 2007. Im Dienste des 'Volkskörpers'. Deutsche und französische Ärzte im Ersten Weltkrieg (In Service of the 'People's Body'. German and French physicians in the First World War) Göttingen: [Vandenhoeck \& Ruprecht] pp. 79-82.

Middlebrook, M., 2001. The First Day of the Somme, London: [Penguin Books] p. 84, 153, $228,266$. 
Mosse, G., 1998. Shell Shock as a social disease. Lecture Peronne 3-7-1998 (unpublished manuscript).

Myers, C.M., 1940. Shell Shock in France 1914-1918. Based on a war diary, Cambridge: [Cambridge University Press] pp. 51-52, 59, 90-91, 95-99, 101, 112, 120-121, 124.

Owen, W., 1997. Disabled, in: Geoff Barton (ed.), Voices of the Great War, Harlow: [Pearson Education], pp. 45-46

Peckl, P., 2011. What the Patient Records Reveal: reassessing the treatment of 'war-neurotics' in Germany (1914-1918), in: Hans-Georg Hofer, Cay-Rüdiger Prüll, Wolfgang U. Eckart (eds.), War, Trauma and Medicine in Germany and Central-Europe (1914-1939), Freiburg:

[Centaurus], pp. 139-159.

Perry, H.R., 2003. Re-arming the disabled veteran. In: Katherine Ott, David Serlin, Stephen Mihm eds., Artificial Parts, Practical Lives. Modern histories of prosthetics, New York/London: [New York University Press ], pp. 75-101.

Perry, H.S., 2005. Recycling the Disabled. Army, medicine and society in World War I Germany, PhD Indiana University, p. 236.

Perry, H.R., 2011. The Thanks of the Fatherland? WWI and the orthopaedic revolution in disability care, in: Hans-Georg Hofer, Cay-Rüdiger Prüll, Wolfgang U. Eckart (eds.), War, Trauma and Medicine in Germany and Central-Europe (1914-1939), Freiburg: [Centaurus], pp. 112-138.

Renn, L., 1929. Krieg, Frankfurt am Main: [Frankfurter Societäts Druckerei] (61.-80.000), p. 374-375 Reznick, J.S., 2000. Work Therapy and the Disabled British Soldier in Great Britain in the First World War: The case of Shepherd's Bush Military Hospital, in: David A. Gerber (ed.), Disabled Veterans in History, Ann Arbor: [University of Michigan Press], pp. 185-203.

Reznick, J.S., 2004. Healing the Nation. Soldiers and the culture of caregiving in Britain during the Great War, Manchester: [Manchester University Press].

Reznick, J.S., 2009. John Galsworthy and disabled soldiers of the Great War, Manchester: [Manchester University Press]

Riedesser, P., Verderber, A., 1985. Aufrüstung der Seelen. Militärpsychiatrie und Militärpsychologie in Deutschland und Amerika, Freiburg: [Dreisam-Verlag], pp. 19, 111. Riemann, H., 1930. Schwester der Vierten Armee. Ein Kriegstagebuch, Berlin: [Karl Voegels Verlag], pp. 205, 214. 
Roudebush, M., 2009. A patient fights back: neurology in the court of public opinion. In: Journal of Contemporary History, 35, 1, pp. 29-38.

Ruprecht, T.M., Jenssen, C. (eds.), 1991. Äskulap oder Mars? Aerzte gegen den Krieg, Bremen: [Donat Verlag], p. 161.

Sassoon, S., 1972. The Complete Memoirs of George Sherston, London: [Faber and Faber] pp. $379,421$.

Schrep, B., 2004. Gebrochen an Leib und Seele (Broken in Body and Soul), in: Spiegel (magazine). Special 1. Über den 1. Weltkrieg und die Folgen (On the First World War and ist Consequences), pp. 58-60.

Shephard, B., 1999. Shell-Shock, In: H. Freeman (ed.), A Century of Psychiatry, London: [Mosby] pp. 33-40.

Shephard, B., 2000. A war of nerves: soldiers and psychiatrists 1914-1994, Harvard: [Harvard University press] pp. 12, 71, 76-78, 98, 104, 135-136, 152.

Simpson, K., 1996. Dr James Dunn and Shell-shock, in: H. Cecil, P.H. Liddle, Facing Armageddon. The First World war experienced, London: [Leo Cooper], 502-522.

Terraine, J.A., 1978. The Inferno: 1914-18, in: Theo Barker (ed.), The Long March of Everyman, Middlesex: [Penguin Books Ltd], 167-199.

Toller, E., 1984, Eine Jugend in Deutschland, Reinbek: [Rohwolt] (orig. 1933), pp. 72-73 Trumbo, D., 1999. Johnny got his Gun, London: [Prion Books] (orig. 1938), p. 205-206 Verdoorn, JA., 1995. Arts en Oorlog. Medische en sociale zorg voor militaire oorlogsslachtoffers in de geschiedenis van Europa (Physician and War. Medical and social care for military war victims in the history of Europe), Rotterdam [Erasmus Publishing], p. 338.

Whalen, RW., 1984. Bitter Wounds. German victims of the Great War, 1914-1939, London: [Cornell University Press] pp. 16-17, 61, 104-105, 121-124, 132, 141, 143, 148-9, 156, 168, 178179, 191.

Whitehead, I., 1997. Third Ypres: casualties and British Medical Services, an evaluation, In: Peter H. Liddle (ed.), Passchendaele in Perspective. The Third Battle of Ypres, London: [Pen \& Sword] pp. $175-200$.

Wilson, T., 1986, The Myriad Faces of War. Britain and the Great War 1914-1918, Oxford: [Polity Press].

Winter, D., 1979. Death's men: soldiers of the Great War, London: [Penguin] pp. 136, 197, 201$202 ; 204,253$. 
Young, A., 1995. The Harmony of Illusions: inventing post-traumatic stress disorder, Princeton, [Princeton University] pp. 61-63, 69-70, 72.

Zweig, S., 1974. Die Welt von Gestern. Erinnerungen eines Europäers (Yesterday's world), Frankfurt am Main: [Fischer Verlag] (orig. 1944), p. 170. 